\title{
Application of Picture Media to Improve Students' English Present Continuous Tense Speaking Ability
}

\author{
Ni Made Milati' ${ }^{10}$ \\ ${ }^{1}$ PGRI Mahadewa University, Denpasar, Indonesia
}

\section{A R T I C L E I N F O}

Article history:

Received September 12, 2021

Revised September 14, 2021

Accepted November 17, 2021

Available online December 25, 2021

Kata Kunci:

Kemampuan Berbicara, Media

Gambar, Present Continuous Tense

Keywords:

Speaking Ability, Picture Media

Present Continuous Tense

DOI:

http://dx.doi.org/10.23887/jpbi.v9i3.4 4416

\section{A B S T R A C T}

The ability to speak English with good and correct pronunciation, accuracy, fluency, and intonation is a challenge for students in forming new knowledge. There are still many students who do not master speaking skills in English. Therefore, this study aims to evaluate the application of image media techniques to students' speaking skills in the present continuous tense. This research is descriptive qualitative research. This research was carried out in three cycles, each consisting of two learning cycles or face-to-face. The research subjects were 30 education participants. The method used to collect data is observation, interviews, and tests. The instrument used to collect data is a test question. The data analysis technique used is descriptive qualitative and quantitative analysis. The results showed that students in cycles I, II, and III had an average score which indicated that image media techniques could improve English speaking skills in the present continuous tense. It was concluded that the application of image media could effectively improve the ability to speak English. Picture media can facilitate students in learning English. This finding can also be used as a reference for teachers to improve the speaking learning process.

This is an open-access article under the CC BY-SA license. Copyright (C) 2021 by Author. Published by Universitas Pendidikan Ganesha.

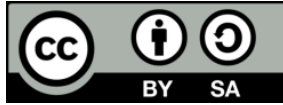

\section{INTRODUCTION}

Language is a tool used to convey or express ideas, opinions, and desires for something both verbally and in writing. All languages have four main components: writing, speaking, listening, and reading (Ho, 2020; Julianti et al., 2016; Maysuroh et al., 2017; Yani, 2021). Speaking is one of the language skills conducted orally by speakers to ensure to ensure others understand their intents and purposes (Arfani \& Sulistia, 2019; Lorena \& Sadiku, 2015; Setyaningsih \& Larassati, 2021). Good speaking ability is a productive skill in learning English because it enables speakers to express their ideas correctly (Feng \& Liu, 2021; Saed et al., 2021; Shamsudin et al., 2013; Yusuf \& Mabagits, 2020). Speaking ability is the competency in pronouncing articulation words to express, and convey thoughts, ideas, and feelings. Speaking is an oral language used to convey intentions, such as ideas, opinions, and feelings, to someone. Speaking skills are used to produce a flow of articulation sound systems to convey wishes, ideas, feelings, and experiences to others (Chien et al., 2020; Escobar Fandiño et al., 2019). The English language consists of four language skills related to each other, namely listening, speaking, reading, and writing (Hengki et al., 2017; Zaretsky, 2020).

There are several stages of students' speaking development, such as listening and speaking productively. Receiving is a speaking stage where students receive more from the learning environment or listen to various speaking styles from others to develop their vocabulary (Alavi \& Akbarian, 2020; Fidiyanti, 2020; Miralpeix \& Muñoz, 2018). Meanwhile, productive speaking is when students have carried out many practices to improve 
their speaking skills. This is followed by students' ability to form and reproduce new expressions, such as asking, explaining, discussing, and even helping colleagues in class (Dwi et al., 2013; Lan \& Lam, 2020; Yusuf \& Mabagits, 2020). Speaking test is a way to conduct an assessment in the form of tasks carried out by students to reduce subjective results. This assessment guide uses the speaking technique to determine the relationship between information, the accuracy of structure, vocabulary, fluency, and pronunciation style (Shamsudin et al., 2013; Sharif Matthews \& López, 2019).

Data collected through observation showed that in 2021, students at the BEC Ubud Institution had several errors associated with their speaking skills. These problems consist of pronunciation, misuse of vocabulary, and grammar, specifically in the present continuous tense material, which increased due to internal and external factors. Present continuous tense is used to express an action or event occurring during a conversation. It is also used to express an action or event that occurs at the time of speaking, a temporary state, and an action or event that has been planned or scheduled, such as an appointment. The internal factors include learning motivation and students' intelligence level, as well as psychological factors, such as low self-confidence in public speaking and the fear of making mistakes during dialogue, specifically in selecting the right tenses. Meanwhile, the external factors are teachers, friends, environment, and learning methods used. Low speaking ability will make students lose their confidence in foreign languages (Liyana \& Kurniawan, 2019; Saed et al., 2021).

Therefore, to overcome the problems mentioned above, this study used the picture media technique to improve students' ability to speak English in the present continuous tense to have clear, definite, and detailed objectives. The picture media is a material used to discuss the learning process and convey messages from teachers to students (Anjelina Putri et al., 2018; Hidayah et al., 2020; Safura et al., 2017). It also helps students to reveal the information contained in the problem, hence, the relationship between the components in the problem becomes clearer (Anjelina Putri et al., 2018; Priani et al., 2019; Tembang \& Suharjo, 2017). Picture media is one of the most effective learning techniques used to improve understanding and increase student learning motivation due to its ability to provide new nuances, thereby eliminating boredom (Asmonah, 2019; Krismasari et al., 2019; Sargeant, 2015). This learning technique attracts attention and also describes a certain fact. Picture media is a medium that uses pictures to convey messages through the sense of sight. The message conveyed is analyzed through visual communication symbols and aims to attract attention, clarify the material, illustrate facts and information (Dewi et al., 2019; Hidayah et al., 2020; Swarastuti, 2019). The general form of picture media is summarized in terms of graphic media for ease in describing and summarizing an idea and event. Graphic media is a visual-based media consisting of symbols, pictures, dots, and lines. Picture media is the most commonly used intermediary because it is understandable and can be enjoyed everywhere (Amali et al., 2020; Nugraha \& Widiana, 2021). The findings of previous studies also stated that picture media would increase students' learning motivation (Hidayah et al., 2020; Priani et al., 2019). Other research findings also state that image media can make it easier for students to understand learning material (Anjelina Putri et al., 2018; Suaeb et al., 2018; Suhandra, 2018). It can be concluded that image media can facilitate students ' learning. This study aims to evaluate the application of image media to improve English speaking skills. The difference between this study and the previous one is that the image media in this study is applied to improve students' speaking English skills in present continuous learning. It is hoped that the image media can improve the ability to speak English in the present continuous lesson.

\section{METHOD}

This research is a descriptive qualitative research consisting of planning, action, observation, and reflection. This research was carried out in three cycles, each consisting of two learning cycles or face-to-face. The research subjects were 30 vocational education (PKK) participants at the BEC Ubud Institute. The methods used to collect data are observation, interviews, and tests. The instrument used to collect data is test questions. The technique used to analyze the data is descriptive qualitative and quantitative analysis. Three types of data analysis were used: reduction, description, and leverage. The process is used to collect, focus, and filter data, describe the source and compare student scores in each cycle based on minimum completeness criteria (KKM). The results of observations, tests, and interviews were compared with the Creswell (2009) triangulation method to validate the collected data (Creswell, 2009).

\section{RESULT AND DISCUSSION}

\section{Result}

Pre-action description. In the early stages, the teaching and learning activities in the classroom were observed and evaluated. Teachers used the conventional learning activities to explain the material and notes required for students to conduct assignments. It was also found that many students found it difficult to generate ideas needed to prepare sentences, eliminate pronunciation mistakes, select the right vocabulary, and compile 
sentences easily using verbs with the present continuous tense pattern. Furthermore, students were less motivated to learn English because the media was monotonous. Based on observations, teachers mostly use teaching materials from textbooks that do not provide sufficient exposure, specifically in speaking practice. Most students need to improve their efficiency in speaking English because their grades are generally low, with an average score of 80 , which is below the minimum criteria. Based on the above reasons, improving students' English speaking skills using a more interesting technique, such as picture media, is necessary. Through this medium, students can directly visualize the activities, objects, and atmosphere observed in the picture. Therefore, they are stimulated to speak English, making it easier for them to generate new ideas by arranging sentences into good paragraphs and telling events in pictures.

Cycle 1. At this stage, the syllabus, lesson plans, pre-and post-tests, student observation sheets for each cycle, collaborator observation sheets, and pictures were prepared according to the material. At the first meeting, the functions, patterns and adverbs of the present continuous often used in sentences were analyzed with example sentences accompanied by pictorial representation using family activities. Besides providing colorful pictures, some of the existing verbs were explained based on changes in the form of the verb-ing. Furthermore, students were asked to analyze the pictures and explain the activities' inherent the content. They are then asked to convey the activities of one person on the picture with the present continuous tense pattern one after another. The observation sheets were filled out during teaching and learning activities for further discussion with collaborators at the reflection stage. Cycle 2 was conducted due to the problems found in the students' present continuous tense speaking skills found in cycle 1. For instance, some find it difficult to speak English because of their inability to understand the present continuous tense and their limited vocabulary. This makes students speak less English with the content of their conversation far different from the topic, without reaching the minimum standard score. In the second cycle, the teaching and learning process was focused on mastering the present continuous tense and vocabulary in school activities.

The teaching and learning process starts with asking students several questions about their understanding of the material. For example: "what is the teacher doing? What are the students doing? Where is the headmaster sitting?" There was progress in students' understanding of the material because almost all were able to answer the questions by telling stories using the present continuous tense. Furthermore, they were guided on the right strategies to discuss with friends to obtain more information about the present continuous tense. In this cycle, students were asked to look for new words related to the topic and guides to translate it into English correctly to enrich their vocabulary. During this process, observation sheets were filled by students and collaborators. Cycle 3. The main activity is to explain the topic related to the atmosphere at work and the hotel.

This process was conducted by reviewing the material on the present continuous tense and providing some questions to determine students' understanding and ability to memorize the material. The simple present continuous tense was used by students to briefly explain the activities that occur within and outside the classroom. Before teachers showed the associated pictures to students, they were asked to discuss the topic with their friends and collect more related-vocabularies. This was followed by showing pictures of activities in the handphone shop to students and asking them to understand the vocabulary needed to explain the atmosphere in their hotel. The minimum score for speaking skills in this research is 80 . Cycle 1 shows that $7(23 \%)$ and $23(77 \%)$ of the students passed and failed the minimum completeness criteria score. The highest, lowest and average scores are 85,55 and 67. In cycle 2, $17(57 \%)$ and $13(43 \%)$ of the students passed and failed the minimum completeness criteria with highest, lowest and average scores of 92, 75 and 80. In cycle 3, $28(98 \%)$ and $2(7 \%)$ of the students passed and failed the minimum completeness criteria with the highest, lowest and average scores of 98, 78 and 85 . The percentage of student success data in the test in each cycle is shown in Figure 1.

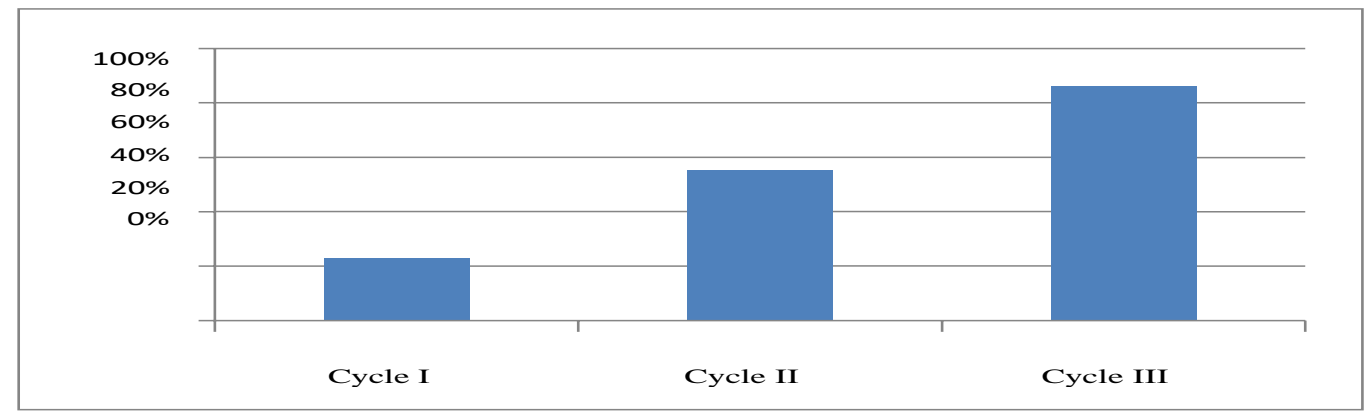

Discussion

Figure 1: Data on the increase in student scores in each cycle

Several observations were used in each cycle, with an increase in students (a) learning motivation, (b) ability to ask and answer questions during learning, (c) rise in confidence in speaking the English language from 
the present continuous tense, and (d) being responsible for their assignments. The interview data results showed that many students do not feel confident in speaking English because they are unable to use the correct pronunciation, right vocabulary, and correct sentence pattern. In addition, students are afraid of making grammatical errors. Media images are very important in the conceptual understanding of members' efforts. Through pictures, the teacher can help provide experience and understanding to students to be wider (Arifiyanti \& Ananda, 2018; Handayani et al., 2017; Rosmalem, 2017). The use of picture media increases students' interest in learning English. This technique increases vocabulary and accelerates good understanding and good mastery of the present continuous tense. The image media used presents the material clearly, making it easier for students to understand the learning material. It is reinforced by previous research, which states that appropriate learning media will make it easier for students to understand learning material quickly (Bus et al., 2020; Khamparia \& Pandey, 2017; Susiana \& Wening, 2015). Students stated that the picture media made it easier for them to understand learning to write descriptive text and choose the right vocabulary when speaking English. Image media is a medium that is very easy to find. Words and pictures are an excellent combination in the process of sending messages, information, or subject matter (Adipta et al., 2016; Hidayati \& Astuti, 2020; Yuliani, 2017). The images presented will provide direction and shadow to students directly regarding the message to be conveyed by the teacher (Krismasari et al., 2019). Simple and clear picture media will also make students have no difficulty understanding the picture.

In general, the application of picture media motivates and makes it easier for students to learn to speak English in the present continuous tense. From the students' answers, it can be concluded that picture media increases enthusiasm and learning techniques for mastering vocabulary based on certain topics in the present continuous tense. The findings of previous studies also stated that picture media increased students' learning motivation (Anggraini et al., 2019; Dewi et al., 2019). Other research findings also state that the help of image media can make it easier for students to understand learning material (Anjelina Putri et al., 2018; Hidayah et al., 2020; Suhandra, 2018). The advantage of image media is that it can overcome the limitations of space and time because not all objects, objects, or events can be brought into the classroom, and students are not always brought to these objects or events. In addition, image media can clarify a problem in any field and for any age. It can be concluded that image media can help students in learning English.

\section{CONCLUSION}

The picture media technique was used to increase students' ability to use the present continuous tense correctly when speaking English. This statement is evidenced by the test results from cycles 1 to 3, which continued to increase.

\section{REFERENCES}

Adipta, H., Maryaeni, M., \& Hasanah, M. (2016). Pemanfaatan Buku Cerita Bergambar Sebagai Sumber Bacaan Siswa SD. Jurnal Pendidikan: Teori, Penelitian, Dan Pengembangan, 1(5), 989-992. https://doi.org/10.17977/jp.v1i5.6337.

Alavi, S. M., \& Akbarian, I. (2020). The role of vocabulary size in predicting performance on TOEFL reading item types. System, 40(3). https://doi.org/10.1016/j.system.2012.07.002.

Amali, L. N., Zees, N., \& Suhada, S. (2020). Motion Graphic Animation Video As Alternative Learning Media. Jambura Journal of Informatics, 2(1). https://doi.org/10.37905/jji.v2i1.4640.

Anggraini, R. D., Listyarini, I., \& Huda, C. (2019). Keefektifan Model Picture And Picture Berbantuan Media Flashcard Terhadap Keterampilan Menulis Karangan. IJEE (Indonesian Journal of English Education), 3(1), 37. https://doi.org/10.23887/ijee.v3i1.17282.

Anjelina Putri, A. A., Swatra, I. W., \& Tegeh, I. M. (2018). Pengaruh Model Pembelajaran PBL Berbantuan Media Gambar Terhadap Hasil Belajar Ipa Siswa Kelas Iii Sd. Mimbar Ilmu, 23(1). https://doi.org/10.23887/mi.v23i1.16407.

Arfani, S., \& Sulistia, A. (2019). Teaching Speaking Using A “Snake And Ladder” Board Game: A Teacher Story. Research and Innovation in Language Learning, 2(1). https://doi.org/10.33603/rill.v2i1.1642.

Arifiyanti, N., \& Ananda, K. (2018). Produksi Kosakata Anak Melalui Electronic Wordless Picture Storybook. RETORIKA, 11(2). https://doi.org/10.26858/retorika.v11i2.6405.

Asmonah, S. (2019). Meningkatkan kemampuan membaca permulaan menggunakan model direct instruction berbantuan media kartu kata bergambar. Jurnal Pendidikan Anak, 8(1), 29-37. https://doi.org/10.21831/jpa.v8i1.26682.

Bus, A. G., Neuman, S. B., \& Roskos, K. (2020). Screens, Apps, and Digital Books for Young Children: The Promise of Multimedia. AERA Open, 6(1), 233285842090149. https://doi.org/10.1177/2332858420901494. 
Chien, S.-Y., Hwang, G.-J., \& Jong, M. S.-Y. (2020). Effects of peer assessment within the context of spherical video-based virtual reality on EFL students' English-Speaking performance and learning perceptions. Computers \& Education, 146. https://doi.org/10.1016/j.compedu.2019.103751.

Creswell, J. W. (2009). Research Design: Qualitative, Quantitative and Mixed Approaches (3rd Edition). In Research Design: Qualitative, Quantitative, and Mixed Methods Approaches. https://doi.org/10.2307/1523157.

Dewi, N. N. K., Kristiantari, M. . R., \& Ganing, N. N. (2019). Pengaruh Model Pembelajaran Picture And Picture Berbantuan Media Visual Terhadap Keterampilan Menulis Bahasa Indonesia. Journal of Education Technology, 3(4). https://doi.org/10.23887/jet.v3i4.22364.

Dwi, N. M. L., Suwatra, I. I. W., \& Rasana, I. D. P. R. (2013). Pengaruh Model Pembelajaran Kooperatif Tipe Inside Outside Circle Terhadap Keterampilan Berbicara Bahasa Inggris Kelas IV SD Gugus X Kecamatan Buleleng. Mimbar PGSD Undiksha, 1(1). https://doi.org/10.23887/jjpgsd.v1i1.746.

Escobar Fandiño, F. G., Muñoz, L. D., \& Silva Velandia, A. J. (2019). Motivation and E-Learning English as a foreign language: A qualitative study. Heliyon, 5(9). https://doi.org/10.1016/j.heliyon.2019.e02394.

Feng, H., \& Liu, H. (2021). International Perspectives on Teaching the Four Skills in ELT: Listening, Speaking, Reading, Writing, Anne Burns, Joseph Siegel, Palgrave Macmillan, Cham (2018), xiv + 260 pp. System, 98. https://doi.org/10.1016/j.system.2021.102467.

Fidiyanti, L. (2020). Penggunaan Media Pembelajaran Flashcard Untuk Meningkatkan Penguasaan Vocabulary Dengan Materi Narrative Teks. Journal of Education Action Research, 4(1), 44. https://doi.org/10.23887/jear.v4i1.23437.

Handayani, N. M. D., Ganing, N. N., \& Suniasih, N. W. (2017). Model Pembelajaran Picture and Picture Berbantuan Media Audio-Visual Terhadap Pengetahuan IPA. Journal of Education Technology, 1(3), 176. https://doi.org/10.23887/jet.v1i3.12502.

Hengki, H., Jabu, B., \& Salija, K. (2017). The Effectiveness of Cooperative Learning Strategy through English Village for Teaching Speaking Skill. Journal of Language Teaching and Research, 8(2), 306. https://doi.org/10.17507/jltr.0802.12.

Hidayah, N., Wahyuni, R., \& Hasnanto, A. T. (2020). Pengembangan Media Pembelajaran Gambar Berseri Berbasis Pop-Up Book Untuk Meningkatkan Keterampilan Menulis Narasi Bahasa Indonesia. Jurnal Pendidikan Dan Pembelajaran Dasar, 7(1). https://doi.org/10.24042/terampil.v7i1.6182.

Hidayati, A., \& Astuti, S. (2020). Pengembangan Media Pembelajaran Buku Kata Bergambar Berbasis Android Untuk Meningkatkan Kemampuan Menulis. Journal for Lesson and Learning Studies, 3(2). https://doi.org/10.23887/j1ls.v3i2.27446.

Ho, Y.-Y. C. (2020). Communicative language teaching and English as a foreign language undergraduates' communicative competence in Tourism English. Journal of Hospitality, Leisure, Sport \& Tourism Education, 27. https://doi.org/10.1016/j.jhlste.2020.100271.

Julianti, R., Atmowardoyo, H., \& Mahmud, M. (2016). University English Teachers and Students' Perceptions of Language Choices in EFL Classroom. ELT Worldwide: Journal of English Language Teaching, 3(2), 204. https://doi.org/10.26858/eltww.v3i2.2258

Khamparia, A., \& Pandey, B. (2017). Impact of interactive multimedia in E-learning technologies: Role of multimedia in E-learning. Enhancing Academic Research With Knowledge Management Principles, April, 199-227. https://doi.org/10.4018/978-1-5225-2489-2.ch007.

Krismasari, D. N. N., Kristiantari, M. G. R., \& Ganing, N. N. (2019). Pengaruh Model Pembelajaran Picture and Picture Berbantuan Media Visual Terhadap Keterampilan Menulis Bahasa Indonesia. Journal of Education Technology, 3(4), 278. https://doi.org/10.23887/jet.v3i4.22364.

Lan, W., \& Lam, R. (2020). Exploring an efl teacher's beliefs and practices in teaching topical debates in mainland China. Iranian Journal of Language Teaching Research, 8(1), 25-44. https://doi.org/10.30466/ijltr.2020.120806.

Liyana, A., \& Kurniawan, M. (2019). Speaking Pyramid sebagai Media Pembelajaran Kosa Kata Bahasa Inggris Anak Usia 5-6 Tahun. Jurnal Obsesi : Journal of Early Childhood Education, 3(1). https://doi.org/10.31004/obsesi.v3i1.178.

Lorena, C., \& Sadiku, M. (2015). The Importance of Four Skills Reading, Speaking, Writing, Listening in a Lesson Hour. European Journal of Language and Literature Studies, 1(1), 29-31. https://doi.org/10.26417/ejls.v1i1.p29-31.

Maysuroh, S., Maryadi, L. I., \& Supiani. (2017). Students' English writing process and problems: A case study at Hamzanwadi University. Voices of English Language Education Society, 1(1). https://doi.org/10.29408/veles.v1i1.388. 
Miralpeix, I., \& Muñoz, C. (2018). Receptive vocabulary size and its relationship to EFL language skills. International Review of Applied Linguistics in Language Teaching, 56(1). https://doi.org/10.1515/iral-2017-0016.

Nugraha, A. A. P. P. Y., \& Widiana, I. W. (2021). Learning Alternative Energy Using Graphic Video Media. International Journal of Elementary Education, 5(2), 224-230. https://doi.org/10.23887/ijee.v5i2.35154.

Priani, I., Manuaba, I. B. S., \& Darsana, I. W. (2019). Pengaruh Model Problem Based Learning (PBL) Berbantuan Media Gambar Terhadap Hasil Belajar IPA Siswa Kelas V Gugus III Kuta Utara Tahun Pelajaran 2017/2018. Mimbar PGSD, 7(1). https://doi.org/10.23887/jjpgsd.v7i1.16972.

Rosmalem. (2017). Peningkatan Aktivitas Belajar Siswa Dengan Model Pembelajaran Picture And Picture Pada Pelajaran Seni Budaya. Jurnal Handayani: Jurnal Kajian Pendidikan Pra Sekolah Dan Pendidikan Dasar, 6(2), 153-161. https://doi.org/10.24114/jh.v6i2.6529.

Saed, H. A., Haider, A. S., Al-Salman, S., \& Hussein, R. F. (2021). The use of YouTube in developing the speaking skills of Jordanian EFL university students. Heliyon, 7(7). https://doi.org/10.1016/j.heliyon.2021.e07543.

Safura, S. S., Suhartiningsih, S., \& Yuliati, N. (2017). Peningkatan Keterampilan Menulis Puisi Bebas Dengan Pilihan Kata Yang Tepat Melalui Penerapan Strategi Writing in the Here and Now Berbantuan Media Gambar Pada Siswa Kelas VA SDN Patrang 01 Jember Tahun Pelajaran 2016/ 2017. Jurnal Edukasi. https://doi.org/10.19184/jukasi.v4i1.5090.

Sargeant, B. (2015). What is an ebook? What is a Book App? And Why Should We Care? An Analysis of Contemporary Digital Picture Books. Children's Literature in Education, 46(4), 454-466. https://doi.org/10.1007/s10583-015-9243-5.

Setyaningsih, N., \& Larassati, A. (2021). "Umm you know..." Speaking or Writing?: Examining EFL Students' Writing Style in Argumentative Essays. Elsya : Journal Of English Language Studies, 3(1). https://doi.org/10.31849/elsya.v3i1.5818.

Shamsudin, S., Sadoughvanini, S., \& Zaid, Y. H. (2013). Iranian EFL Learners' Collocational Errors in Speaking Skill. Procedia - Social and Behavioral Sciences, 70. https://doi.org/10.1016/j.sbspro.2013.01.190.

Sharif Matthews, J., \& López, F. (2019). Speaking their language: The role of cultural content integration and heritage language for academic achievement among Latino children. Contemporary Educational Psychology, 57, 72-86. https://doi.org/10.1016/j.cedpsych.2018.01.005.

Suaeb, S., Degeng, I. N. S., \& Amirudin, A. (2018). Meningkatkan Hasil Belajar IPS Siswa Kelas V melalui Penerapan Pembelajaran Kooperatif Model Teams Games Tournament ( TGT ) Berbantuan Media Tebak Gambar. Jurnal Pendidikan: Teori, Penelitian, Dan Pengembangan, 3(1), 146-154. https://doi.org/10.17977/jptpp.v3i1.10435.

Suhandra, I. R. (2018). Pemanfaatan media gambar berseri untuk memperkaya kemampuan menulis naratif bahasa inggris siswa kelas IX MTS NW Nurul Wathon Pengembur Lombok Tengah. $\begin{array}{llll}\text { TRANSFORMASI: } \quad \text { Jurnal } & \text { Masyarakat, } & \text { 14(1). }\end{array}$ https://doi.org/10.20414/transformasi.v14i1.576.

Susiana, R., \& Wening, S. (2015). Pengaruh Model Direct Instruction Berbantuan Multimedia Terhadap Motivasi Belajar Dan Pencapaian Kompetensi Pembuatan Desain Busana. Jurnal Vokasi Pendidikan, 5(3). https://doi.org/10.21831/jpv.v5i3.6491.

Swarastuti, A. (2019). The Impact Of Picture Series Towards Students' Ability In Writing Narrative Text. Edukasi Lingua Sastra, 17(1). https://doi.org/10.47637/elsa.v17i1.108.

Tembang, Y. S., \& Suharjo. (2017). Peningkatan Motivasi Dan Hasil Belajar Melalui Model Pembelajaran Think Pair Share Berbantuan Media Gambar Di Sekolah Dasar. Jurnal Pendidikan Universitas Negeri Malang, 2(6), 812-817.

Yani, A. (2021). English teachers' perception on the quality of online learning during covid-19. Journal of English Language Teaching and Linguistics, 3(1). https://doi.org/10.21462/jeltl.v6i2.600.

Yuliani, H. (2017). Pembelajaran Fisika menggunakan Media Animasi Macromedia Flash-MX dan Gambar untuk Meningkatkan Pemahaman Konsep Mahasiswa. Jurnal Ilmiah Pendidikan Fisika Al-Biruni, 6(1), 13-21. https://doi.org/10.24042/jpifalbiruni.v6i1.596.

Yusuf, K., \& Mabagits, S. (2020). Does Activeness in Organization Improve English Speaking Skill? University Students' Perspective. Leksika Jurnal Bahasa, Sastra Dan Pengajarannya, 14(2). https://doi.org/10.31838/jcr.07.12.41.

Zaretsky, E. (2020). English spelling acquisition by English Language Learners from Spanish-speaking background: The role of cognitive and linguistic resources and L1 reading status. Cognitive Development, 55. https://doi.org/10.1016/j.cogdev.2020.100918. 